BENM 2021

International Scientific and Practical Conference "Biotechnology, Ecology, Nature Management"

\title{
THE QUALITY MONITORING OF COMBINED FEEDS FOR TRUT AND STURGEON FISHES
}

\author{
A. A. Klimuk (a)*, S. V. Beketov (b), L. L. Brezhnev (c), I. R. Selivanova (d) \\ *Corresponding author
}

(a) K.G. Razumovsky Moscow State University of Technologies and Management (the First Cossack University), 73, Zemlyanoy Val str., Moscow, Russia, klimukanastasia27@gmail.com

(b) K.G. Razumovsky Moscow State University of Technologies and Management (the First Cossack University), 73, Zemlyanoy Val str., Moscow, Russia, svbeketov@gmail.com

(b) K.G. Razumovsky Moscow State University of Technologies and Management (the First Cossack University), 73, Zemlyanoy Val str., Moscow, Russia, brezhnev2011@list.ru

(d) K.G. Razumovsky Moscow State University of Technologies and Management (the First Cossack University), 73, Zemlyanoy Val str., Moscow, Russia, i.selivanova@mgutm.ru

\begin{abstract}
A comparative analysis of the quality of mixed feed for trout and sturgeon fishes of domestic and foreign production is carried out. In the course of the study, the quality of crude protein, crude fat and the acidity of the compound feed were determined. Taking into account the possible risks when breeding valuable fish species, the importance of systematic monitoring of the quality of feed is noted, which will make it possible to obtain an actual assessment of their condition. According to the data obtained, it was found that the samples of compound feed for trout and sturgeon, regardless of the manufacturer, met the requirements and standards for the quality of crude protein and fat. At the same time, in addition to the peroxide value of fat, it is necessary to use such estimated indicators of crude protein as the level of total volatile nitrogen and ammonia, as well as the $\mathrm{pH}$ of the compound feed.
\end{abstract}

2672-8575 @ 2022 Published by European Publisher.

Keywords: Ammonia, feed quality, peroxide value, $\mathrm{pH}$. , total volatile nitrogen 


\section{Introduction}

Providing aquaculture facilities with balanced nutritional value and safe quality feed is today the main task of fish breeding and raising enterprises. The state of the main nutrients of compound feed (crude protein and crude fat) directly affects the growth rate and health of aquatic organisms, and can also directly cause their death (Nikiforov-Nikishin, Shatokhin et al., 2019) In this connection, monitoring the quality of feed becomes an important and necessary element correct organization of fish farming.

At the same time, the most acceptable methods for monitoring feed quality are the determination of amino-ammonia nitrogen and ammonia (color reaction) for crude protein and peroxide value for crude fat. These methods meet the basic requirements for chemical analyzes - they are simplicity, economy, selectivity, rapidity, correctness, reproducibility, and accuracy.

The method for the determination of amino-ammonia nitrogen (AAA) is based on the titration of free carboxyl groups in an aqueous extract of the analyzed product in the presence of formalin with alkali. In this case, free amino groups are bound by formalin, and free carboxyl groups are titrated with alkali (GOST R 51487-99, 2008).

Since amino-ammonia nitrogen means not only harmful nitrogen-containing compounds formed in the process of putrefactive transformation of proteins, such as ammonia (NH3), amines (methylamine, dimethylamine, trimethylamine, histamine, etc.), amino alcohols, etc., but also amino acids , vitamins, it makes sense to supplement the assessment of the AAA level with the method for determining ammonia and ammonia salts in the aqueous extract of compound feed (color reaction) (Guidelines for food sanitary analysis using test means, 2014).

The essence of this approach lies in the fact that Nessler's reagent, when interacting with ammonia (free and bound), amines, creatinine, and some primary protein breakdown products, forms colored mercuramide compounds, while amino acids and purine bases (structural elements of DNA) in this reaction do not participate (Berestov \& Taranov, 1983; Lazarevsky, 1955). This makes it possible to exclude the influence of free amino acids and vitamins present in feed on the results of analyzes (Beketov \& Praded, 2020).

As for the quality of fat, out of the many proposed laboratory methods for its determination, the most effective is the peroxide number - a quantitative indicator of the presence of primary oxidation products of peroxides and hydroperoxides. In other words, by the magnitude of the peroxide number, one can judge already about the initial stage of lipid oxidation, that is, even before the appearance of an unpleasant taste and smell.

The assessment of the quality of the compound feed can be supplemented by determining its $\mathrm{pH}$ ( $\mathrm{pH}$ value).

\section{Problem Statement}

The essence of this approach lies in the fact that Nessler's reagent, when interacting with ammonia (free and bound), amines, creatinine, and some primary protein breakdown products, forms colored mercuramide compounds, while amino acids and purine bases (structural elements of DNA) in this reaction do not participate (Berestov \& Taranov, 1983; Lazarevsky, 1955). 


\section{Purpose of the Study}

A comparative analysis of the quality of mixed feed for trout and sturgeon fishes of domestic and foreign production is carried out. In the course of the study, the quality of crude protein, crude fat and the acidity of the compound feed were determined.

\section{Research Methods}

The work was carried out at the Institute of Biotechnology and Fisheries K.G. Razumovsky Moscow State University of Technologies and Management (the First Cossack University)

The material for the research was fodder for trout and sturgeon fish of domestic and foreign production. A total of 6 samples were examined, representing extruded feed, crumbs and granules. By the nature of the application, the studied compound feed was classified as starting and production, optimal and economical.

Sample 1 was an extruded food for trout (diameter (ø) $6 \mathrm{~mm}$ ) (Russia); sample 2 - compound feed for sturgeon (ø $3 \mathrm{~mm}$ ) (Russia); sample 3 - food for beluga, sterlet, stellate sturgeon, Russian, Siberian and white sturgeon, paddlefish and other sturgeon species (ø $2 \mathrm{~mm}$ ) (Germany); sample 4 - food for aquarium fish (tetras, guppies and other tropical species), as well as for fry of sturgeon, trout, whitefishes, tilapia and catfish (ø 0.8-1.2 mm) (Germany); sample 5 - food for trout and sturgeon (ø $3 \mathrm{~mm})$ (Germany); sample 6 - food for sturgeon (ø $3 \mathrm{~mm}$ ) (Germany).

The sanitary-chemical quality of protein in compound feed for fish was determined by the content of amino-ammonia nitrogen (GOST R 55479-2013, 2014), ammonia (Guidelines for sanitary-food analysis using test means, 2014). Peroxide number of fat - using a method based on the reaction of interaction of lipid oxidation products (peroxides and hydroperoxides) in the tested feed with potassium iodide in a solution of acetic acid and chloroform and subsequent quantitative determination of the released iodine with a solution of sodium thiosulfate (GOST R 51487-99, 2008).

The $\mathrm{pH}$ level in compound feed for fish was determined by the potentiometric method (Beketov, 2015).

\section{Findings}

The results of studies of compound feed for fish (trout and sturgeon) are presented in Tables 1 and 2. In particular, the aqueous extracts of compound feed after the addition of Nessler's reagent (color reaction to ammonia) acquired a color from light to dark green. At the same time, in none of the samples under study, during the reaction, the appearance of an orange color of the solution with the precipitation of a flocculent precipitate was noted, which indicates the permissible values of ammonia (Beketov \& Praded, 2020).

Table 1. Results of the analysis of the quality of crude protein in compound feed for trout and sturgeon

\begin{tabular}{cccc}
\hline Compound feed for fish & Crude & \multicolumn{2}{c}{ Determination of protein quality } \\
& protein, $\%$ & amino-ammonia & ammonia \\
nitrogen (AAA), $\mathrm{mg}^{2}$ & (color reaction) \\
\hline
\end{tabular}




\begin{tabular}{cccc}
\hline Trout (ø $6 \mathrm{~mm})$ (Russia) & 42 & 167,9 & light green \\
Sturgeon (ø 3 mm) (Russia) & 50 & 100 & dark green \\
Sturgeon (ø $2 \mathrm{~mm}$ ) (Germany) & 45 & 67,5 & light green / dark green \\
Sturgeon and trout fry (ø 0.8-1.2 mm) & 46 & 51 & light green \\
(Germany) & 39,9 & 178,6 & light green \\
Trout, sturgeon (ø $3 \mathrm{~mm})$ (Germany) & 45 & 79 & light green \\
Sturgeon (ø $3 \mathrm{~mm}$ ) (Germany) & & & \\
\hline
\end{tabular}

In turn, the samples of compound feed for fish were characterized by different levels of aminoammonia nitrogen (AAA), which varied from 51 to $178.9 \mathrm{mg} \%$. The smallest AAA values were obtained on starting compound feeds made in Germany: samples $3(\varnothing 2 \mathrm{~mm})$ and 4 (ø 0.8-1.2 mm), respectively 51 and $67.5 \mathrm{mg} \%$, and the highest on production - sample 1, compound feed (ø $6 \mathrm{~mm}$ ) produced in Russia and sample 6, compound feed (ø $3 \mathrm{~mm}$ ) produced in Germany, respectively 178.6 and $167.9 \mathrm{mg} \%$. At the same time, there was no connection between the indicators of crude protein, amino-ammonia nitrogen and ammonia. In this connection, we cannot say that the compound feed from Germany (sample 6) is worse than the compound feed produced in Russia (sample 1), since a consequence of the higher value of the amino-ammonia nitrogen indicator may be the introduction of free amino acids or hydrolyzed dry animal feed (Klimuk et al., 2019).

Table 2. The results of the analysis of the quality of raw fat and $\mathrm{pH}$ in compound feed for trout and sturgeon

\begin{tabular}{ccccc}
\hline Compound feed for fish & Crude protein,\% & \multicolumn{2}{c}{ Peroxide number } & pH \\
\cline { 3 - 4 } & & mmol / kg 1/2 O & \%J2 & 5,92 \\
Trout (ø 6 mm) (Russia) & 24 & 6 & 0,077 & 6,4 \\
Sturgeon (ø 3 mm) (Russia) & 15 & 3,34 & 0,043 & 6,4 \\
Sturgeon (ø 2 mm) (Germany) & 18 & 5,7 & 0,073 & 5,82 \\
Sturgeon and trout fry (ø 0.8-1.2 & 10 & - & - & 6,19 \\
mm) (Germany) & 20,6 & 6 & 0,077 & 6,42 \\
Trout, sturgeon (ø 3 mm) & 21 & 4,97 & 0,064 & \\
(Germany) & & & & \\
Sturgeon (ø 3 mm) (Germany) & & & & \\
\hline
\end{tabular}

Analyzing the data in Table 2, it can be noted that despite the fact that the fats of the considered compound feeds differed in different degrees of oxidation (from the absence in sample 4 to $0.077 \% \mathrm{~J} 2$ in samples 1 and 5), none of the compound feeds exceeded the maximum permissible concentration in terms of peroxide content. number equal to $0.2 \% \mathrm{~J} 2$ (Sklyarov, 2008).

As for the $\mathrm{pH}$ level, it was in a position close to neutral (from 5.82 in sample 4 to 6.42 in sample $6)$.

\section{Conclusion}

According to the data obtained, it was found that the samples of compound feed for trout and sturgeon, regardless of the manufacturer, met the requirements and standards for the quality of crude protein and fat (Nikiforov-Nikishin, Nikiforov-Nikishin et al., 2021). At the same time, in addition to the 
peroxide value of fat, it is important to use such estimated indicators of crude protein as the level of amino-ammonia nitrogen, ammonia, as well as the $\mathrm{pH}$ of the feed.

For example, ammonia intoxication can lead to a change in the direction of metabolism and the development of non-infectious necrosis of the gills, in which up to $80 \%$ of reared juveniles die (Lopukhina, 1969; Shchelkunov, 1988), and a shift in $\mathrm{pH}$ towards the alkaline side creates favorable conditions for development in the gastrointestinal path of fish pathogenic microflora (Burlachenko, 2008).

Thus, taking into account the risks in breeding valuable fish species, it becomes necessary to systematically monitor compound feed, with the promptest analysis of the quality indicators of crude protein, crude fat and $\mathrm{pH}$. This is due to the fact that spoilage of feed can be caused not only by initially low-quality components, but also by the conditions of transportation and storage.

\section{References}

Beketov, S. V. (2015). PH measurement in feed for fur animals. Rabbit and fur farming, 5, $26-28$.

Beketov, S. V., \& Praded, M. N. (2020). Analysis of the quality of protein in dry animal feed: a methodological guide. Printing house LLC "PolyPrint" 20.

Berestov, V. A., \& Taranov, G. S. (1983). Laboratory methods for assessing the quality of feed in fur farming. Karelia.

Burlachenko, I. V. (2008). Topical issues of feed safety in fish aquaculture. VNIRO.

GOST R 51487-99. (2008). Vegetable oils and animal fats. Peroxide value determination method. - M.: FGUP "Standartinform".

GOST R 55479-2013. (2014). Meat and meat products. Methods for the determination of aminoammonia nitrogen. FGUP "Standartinform".

Guidelines for Food Sanitation Analysis Using Test Agents. (2014). "Krismas +".

Klimuk, A. A., Egorov, G. A., \& Praded, M. N. (2019). Sanitary and Chemical Quality of Feather Meal Used in Aquaculture. New Conceptual Approaches to Solving the Global Problem of Ensuring Food Security in Modern Conditions. Collection of articles of the VI International Scientific and Practical Conference on November 15, 165.

Lazarevsky, A. A. (1955). Techno-chemical control in the fish processing industry. Pishchepromizdat.

Lopukhina, A. M. (1969). Materials on the etiology and epizootology of gill disease in carp. Izvestia GosNIORKh. Infectious diseases of fish and their control. GosNIORKH, 69, 124-137.

Nikiforov-Nikishin, A., Nikiforov-Nikishin, D., Kochetkov, N., Smorodinskaya, S., \& Klimov, V. (2021). The influence of probiotics of different microbiological composition on histology of the gastrointestinal tract of juvenile Oncorhynchus mykiss. Microscopy Research and Technique. https://doi.org/10.1002/jemt.23927

Nikiforov-Nikishin, A. L., Shatokhin, M. V., Ponomarev, A. K., Golovacheva, N. A., Borodin, A. L., Zaitseva, N. A., \& Larionova, A. A. (2019). The Influence of Anthropogenic Factors on the Ecological Status of the Spawning Grounds of Lake Senezh. Ekoloji, 28(107), 341-48.

Shchelkunov, I. S. (1988). Fish gill necrosis. Fisheries: express information. TSNIITEIRKH, 4, 22.

Sklyarov, V. Ya. (2008). Fish feed and feeding in aquaculture. VNIRO Publishing House. 